Journal of Advanced Research in Fluid Mechanics and Thermal Sciences

\title{
A Simulation Study on Temperature Uniformity of Photovoltaic Thermal Using Computational Fluid Dynamics
}

\author{
Mohd Afzanizam Mohd Rosli ${ }^{1,2,{ }^{*}}$, Irfan Alias Farhan Latif ${ }^{1}$, Muhammad Zaid Nawam ${ }^{1}$, Mohd Noor \\ Asril Saadun ${ }^{1,2}$, Hasila Jarimi ${ }^{3}$, Mohd Khairul Anuar Sharif ${ }^{4}$, Sulaiman Ali ${ }^{5}$

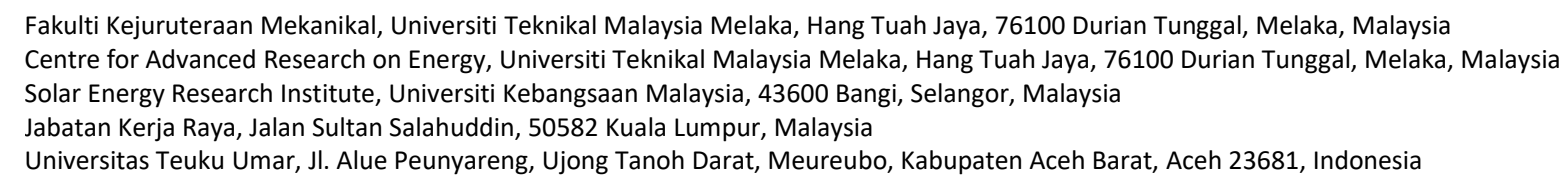

\section{ARTICLE INFO}

Article history:

Received 3 December 2020 Received in revised form 2 March 2021 Accepted 10 March 2021 Available online 7 April 2021

\section{Keywords:}

Photovoltaic Thermal; Temperature Distribution; Computational Fluid Dynamics; Simulation

\section{ABSTRACT}

\section{Introduction}

The energy demand has seen a sudden increase in recent years due to the increase in population and the rapid advancement of technology [1]. According to the International Energy Agency, global energy consumption rates are expected to rise by up to $37 \%$ by 2040 [2]. In recent years, to match this increase in demand and to decrease the depletion rate of natural resources while avoiding greenhouse gas emissions in energy generation, renewable energy resources such as wind, solar,

\footnotetext{
* Corresponding author.

E-mail address: afzanizam@utem.edu.my
}

https://doi.org/10.37934/arfmts.82.1.2138 
hydro, biomass, and geothermal energy are being used for energy generation [3]. Solar energy is one of the best options due to its high potential and availability across many regions worldwide. However, it is still considered an expensive source for electrical energy generation due to inefficient technology. Even though it is inefficient, solar power still possesses the most potential for power generation [4]. Therefore, a lot of research work is being done to improve the technology in recent years. Abdullah et al., [5] does a useful review of the recent advancements made in solar photovoltaic thermal (PVT) technology. While Sachit et al., [6] focuses on the flat plate type photovoltaic (PV) systems. Photovoltaic (PV) cells are used to convert solar energy into electrical energy, and thermal energy is produced as well. PV panels typically have electrical efficiency in the range of $4-17 \%$, depending on the operating conditions [7]. Most solar irradiance is converted into thermal energy instead. This thermal energy raises the temperature of PV cells, which causes a decline in the electricity generation and efficiency and can also lead to permanent damage due to high thermal stress levels [8,9].

To solve this problem, solar photovoltaic thermal (PVT) systems are used, which take the thermal energy away from the PV cells allowing them to work under lower temperatures, thus increasing their efficiency $[9,11]$. Solar PVTs use various cooling fluids to extract thermal energy. Various techniques are used to improve the heat transfer between the cooling fluid and the PV module, which influences the efficiency of the system. Some studies focus on the working fluid, which normally is either air (less efficient) or water [12]. But it can be changed to achieve better thermal efficiency using various nanofluids [7,13-16].

Another approach for improving efficiency is by changing the absorber configuration. Absorbers can be configured in many shapes such as serpentine, parallel, spiral, or other custom shapes like Misha designs as shown in Figure $1[17,18]$. When compared with each other, the spiral arrangement is found to be most efficient $[2,19,20]$. Studies have also compared different tube shapes for the absorbers. Round tubes are found to be more efficient as they allow for better flow even though square tubes have better contact area with the absorber plate $[2,20]$.

Table 1 shows the thermal and electrical efficiencies obtained by various studies present in literature. Where ' $T_{a}$ ' is the ambient temperature, ' $W_{s}$ ' is the wind speed, ' $I_{r}$ ' is the solar radiation, ' $T_{s}$ ' is the temperature of the sky and ' $T_{i}$ ' is the inlet temperature.

The performance of the PVT system depends heavily on operating conditions. This is explored to a high degree in literature. However, temperature uniformity also affects the performance of a PVT system-non-uniform temperature distribution results in regions of hotspots (areas of high temperatures). The cells in these regions perform poorly compared to other cells due to high temperature, resulting in decreased efficiency due to lower power generation. These temperature hotspots can also cause permanent damage to the PV cells due to high thermal stresses. Therefore, temperature uniformity is an essential factor in increasing the performance and PV panels' lifetime [9]. The temperature uniformity is extensively studied by Bahaidarah et al., [9] for both concentrating and non-concentrating PV systems. The importance of uniform cooling is signified by the mention of adverse effects on performance due to non-uniform temperatures across the PV due to shading and inconsistent irradiance levels across the PV system. In a series combination of PV cells, the overall current produced by the module is restricted to the minimum current produced by a cell in a hotspot [9]. Because of this, the performance of PV panels is usually determined by the hotspots [31]. 
Table 1

Efficiency studies in recent years on PVT systems

\begin{tabular}{|c|c|c|c|c|c|}
\hline Reference & $\begin{array}{l}\text { Thermal } \\
\text { Collector }\end{array}$ & Operating Conditions & $\begin{array}{l}\text { Thermal } \\
\text { Efficiency }\end{array}$ & $\begin{array}{l}\text { Electrical } \\
\text { Efficiency }\end{array}$ & Type of Study \\
\hline $\begin{array}{l}\text { Wang et al., } \\
{[21]}\end{array}$ & Fresnel & $\begin{array}{l}T_{a}=30^{\circ} \mathrm{C}, W_{s}=3 \mathrm{~m} / \mathrm{s} \\
I_{r}=960 \mathrm{~W} / \mathrm{m}^{2}\end{array}$ & $79 \%$ & $8.7 \%$ & Theoretical \\
\hline $\begin{array}{l}\text { Valizadeh et } \\
\text { al., [22] }\end{array}$ & $\begin{array}{l}\text { Parabolic } \\
\text { Trough }\end{array}$ & $\begin{array}{l}T_{a}=25^{\circ} \mathrm{C}, T_{s}=19^{\circ} \mathrm{C}, W_{s}=5 \mathrm{~m} / \mathrm{s} \\
I_{r}=1000 \mathrm{~W} / \mathrm{m}^{2}, T_{i}=70^{\circ} \mathrm{C}\end{array}$ & $67 \%$ & $22 \%$ & Theoretical \\
\hline Yu et al., [23] & Flat Plate & $\begin{array}{l}T_{a}=23.6^{\circ} \mathrm{C}, W_{s}=3 \mathrm{~m} / \mathrm{s} \\
I_{r}=940 \mathrm{~W} / \mathrm{m}^{2}\end{array}$ & $25.2 \%$ & $11.8 \%$ & $\begin{array}{l}\text { Theoretical \& } \\
\text { Experimental }\end{array}$ \\
\hline $\begin{array}{l}\text { Abd El-Samie } \\
\text { et al., [24] }\end{array}$ & $\begin{array}{l}\text { Compound } \\
\text { Parabolic }\end{array}$ & $T_{i}=25.1^{\circ} \mathrm{C}$ & $50.6 \%$ & $7.3 \%$ & Theoretical \\
\hline $\begin{array}{l}\text { Bellos and } \\
\text { Tzivanidis } \\
\text { [25] }\end{array}$ & $\begin{array}{l}\text { Parabolic } \\
\text { Trough }\end{array}$ & $T_{i}=25^{\circ} \mathrm{C}, I_{r}=1000 \mathrm{~W} / \mathrm{m}^{2}$ & $46.84 \%$ & $6.6 \%$ & Theoretical \\
\hline $\begin{array}{l}\text { Adam et al., } \\
{[26]}\end{array}$ & $\begin{array}{l}\text { Fresnel, } \\
\text { Parabolic } \\
\text { Trough }\end{array}$ & $\begin{array}{l}T_{a}=25^{\circ} \mathrm{C}, T_{i}=20^{\circ} \mathrm{C} \\
I_{r}=1000 \mathrm{~W} / \mathrm{m}^{2}\end{array}$ & $55 \%, 70 \%$ & $5 \%, 18 \%$ & Theoretical \\
\hline $\begin{array}{l}\text { Jaaz et al., } \\
{[27,28]}\end{array}$ & $\begin{array}{l}\text { Compound } \\
\text { Parabolic }\end{array}$ & $T_{a}=33^{\circ} \mathrm{C}, I_{r}=800 \mathrm{~W} / \mathrm{m}^{2}$ & $81 \%$ & $13.75 \%$ & Experimental \\
\hline $\begin{array}{l}\text { Proell et al., } \\
\text { [29] }\end{array}$ & $\begin{array}{l}\text { Compound } \\
\text { Parabolic, } \\
\text { Flat Plate }\end{array}$ & $\begin{array}{l}T_{a}=17-29^{\circ} \mathrm{C} \\
I_{r}=1000 \mathrm{~W} / \mathrm{m}^{2}\end{array}$ & $34 \%$ & $9 \%$ & Experimental \\
\hline $\begin{array}{l}\text { Yazdanifard } \\
\text { et al., [30] }\end{array}$ & $\begin{array}{l}\text { Parabolic } \\
\text { Trough, } \\
\text { Flat Plate }\end{array}$ & $\begin{array}{l}T_{a}=25^{\circ} \mathrm{C}, T_{i}=25^{\circ} \mathrm{C} \\
W_{s}=1.5 \mathrm{~m} / \mathrm{s}, I_{r}=700 \mathrm{~W} / \mathrm{m}^{2},\end{array}$ & $\begin{array}{l}52.58 \% \\
- \\
56.37 \%\end{array}$ & $\begin{array}{l}7.12 \% \\
- \\
7.94 \%\end{array}$ & Theoretical \\
\hline $\begin{array}{l}\text { Hosseinzadeh } \\
\text { et al., [7] }\end{array}$ & Flat Plate & $\begin{array}{l}T_{a}=30^{\circ} \mathrm{C}, T_{i}=40^{\circ} \mathrm{C} \\
I_{r}=900 \mathrm{~W} / \mathrm{m}^{2}\end{array}$ & $56 \%$ & $14.4 \%$ & $\begin{array}{l}\text { Theoretical } \\
\& \\
\text { Experimental }\end{array}$ \\
\hline $\begin{array}{l}\text { Misha et al., } \\
{[16]}\end{array}$ & Flat Plate & $\begin{array}{l}W_{s}=1 \mathrm{~m} / \mathrm{s}, T_{i}=26^{\circ} \mathrm{C} \\
I_{r}=600-1000 \mathrm{~W} / \mathrm{m}^{2}\end{array}$ & $59.6 \%$ & $11.71 \%$ & $\begin{array}{l}\text { Theoretical \& } \\
\text { Experimental }\end{array}$ \\
\hline
\end{tabular}

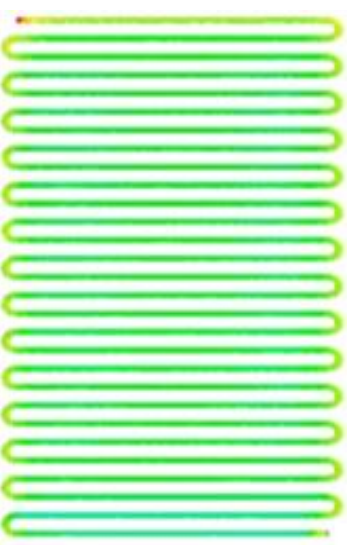

(a)

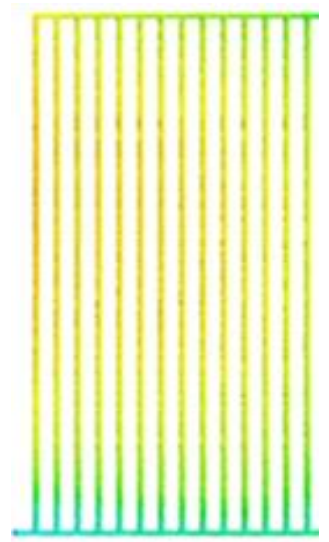

(b)

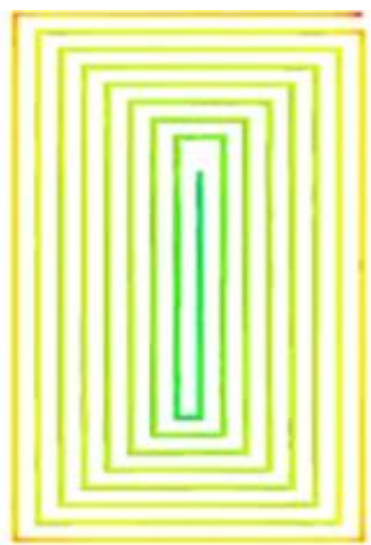

(c)

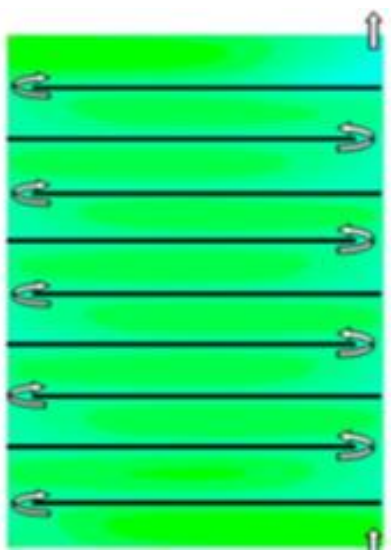

(d)

Fig. 1. (a) Serpentine absorber, (b) Parallel absorber, (c) Spiral Absorber, (d) Cross fined absorber (for air) [2]

Not many studies focus primarily on temperature uniformity on the PV module. That is because temperature uniformity is more prevalent in the concentration PV systems [32]. However, it should not be neglected for flat-plate PV systems [33]. The limited studies that mention the effects of temperature uniformity point towards performance gains due to better uniformity. Mohammad highlights the bypass diode effect, which hurts performance due to uneven temperatures across the PV induced by partial shading [34]. When using air, a better temperature distribution is observed 
across the PV. Nevertheless, at the same time, the air is not a good conductor of heat as compared to water. Nevertheless, when using liquid cooling techniques, the temperature distribution becomes uneven.

Many parameters affect the temperature uniformity and efficiency of PV panels, such as ambient wind speed, incident solar irradiation, ambient air temperature, coolant inlet temperature, coolant mass flow rate, absorber tube spacing, absorber tube length, and absorber configuration, etc. The effect of tube spacing on temperature uniformity is highlighted by Zhou et al., [33]. They concluded that with a small tube spacing, better uniformity of temperature distribution is observed. High ambient wind speed results in high convection on the top glass surface resulting in lower temperatures, i.e., high electrical efficiency. However, this results in lower thermal efficiency due to more heat loss to ambient. The effect of wind speed on temperature uniformity is not significant [7]. High solar irradiation causes high temperatures on the cells. This results in lower electrical efficiency. However, if the PVT system has good thermal efficiency, PV cells can operate at higher irradiation levels with good electrical efficiencies. Low coolant inlet temperatures lead to better thermal and electrical efficiency [7]. A high mass flow rate leads to better electrical and thermal efficiency [7]. However, for uniformity, the inlet velocity/flow rate does not play a significant role [33]. The spiral absorber can lead to better thermal efficiency due to increased pipe length and the surface contact area between tubes and the module.

In summary, for best uniformity of temperature on PV panels, a spiral absorber (because it gives a better contact area between pipe and module) with low values of tube spacing, aluminium/copper as the absorber plate material, and an optimum flow rate based on the absorber pipe dimensions is recommended. Usually, a high flow rate results in better heat transfer [33].

In this article, a PVT system with a custom absorber configuration is designed and tested which will ensure an improved and more uniform temperature distribution across the PV plate. This custom absorber will be optimized based on the previous literature. This new absorber design should give better temperature distribution across the PV plate surface, which will help with prolonging the lifetime of the panel and its overall efficiency. A simulation model is prepared and validated by an experimental study [7]. The new absorber is then tested in terms of performance and temperature uniformity in this simulation model and its performance is compared with that of the absorber used in the experimental study [7]. There have been studies that explore temperature uniformity. Figure 2 shows the research gap found in these studies which is contributed towards by this article.

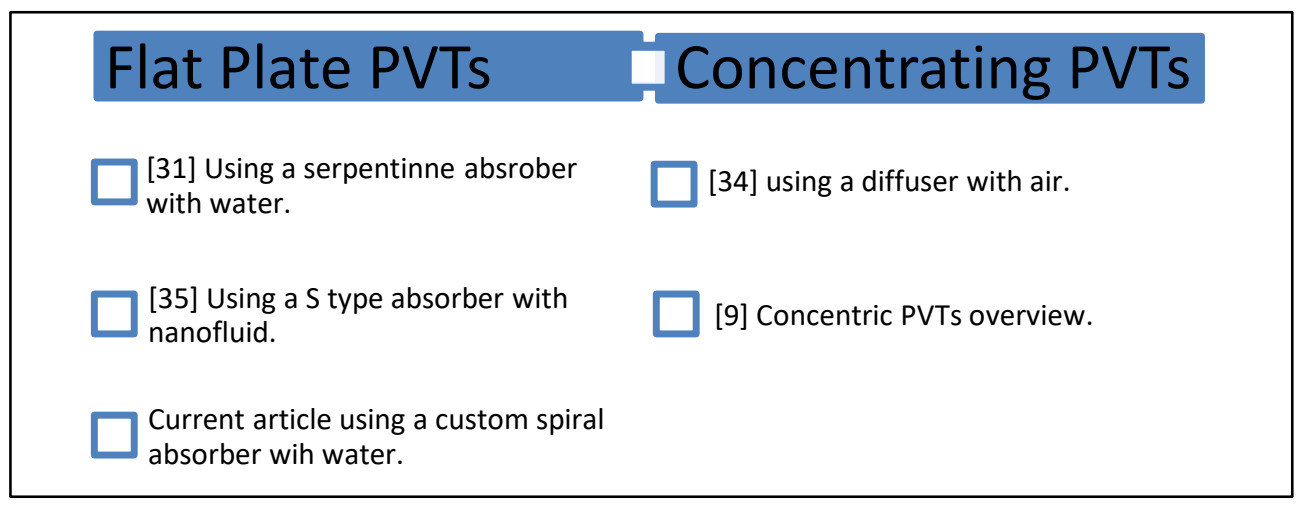

Fig. 2. Research gap demonstration for temperature uniformity 


\section{Methodology}

The model consists of a typical monocrystalline silicon PV module. The module is coupled with an absorber made of copper, having water as its working fluid. The geometric model for the simulation is made in Design Modeler and consists of a glass, PV module, absorber plate, thermal contact paste, absorber pipe, and insulation body as shown in Figure 3. Layers such as the ARC protective layer and the tedlar are excluded from the model due to their very small size $(0.0001 \mathrm{~m})$. At the same time, EVA layers are considered to be $100 \%$ transparent and therefore also excluded from the model for further simplification [31].

The properties of the different materials and the dimensions of layers used in the model are borrowed from the studies of Hosseinzadeh et al., [7], Fayaz et al., [35], and Filipović et al., [36] are shown in Table 2 and Table 3, respectively. The properties of insulation material are absent from the study. These properties are estimated as wood.
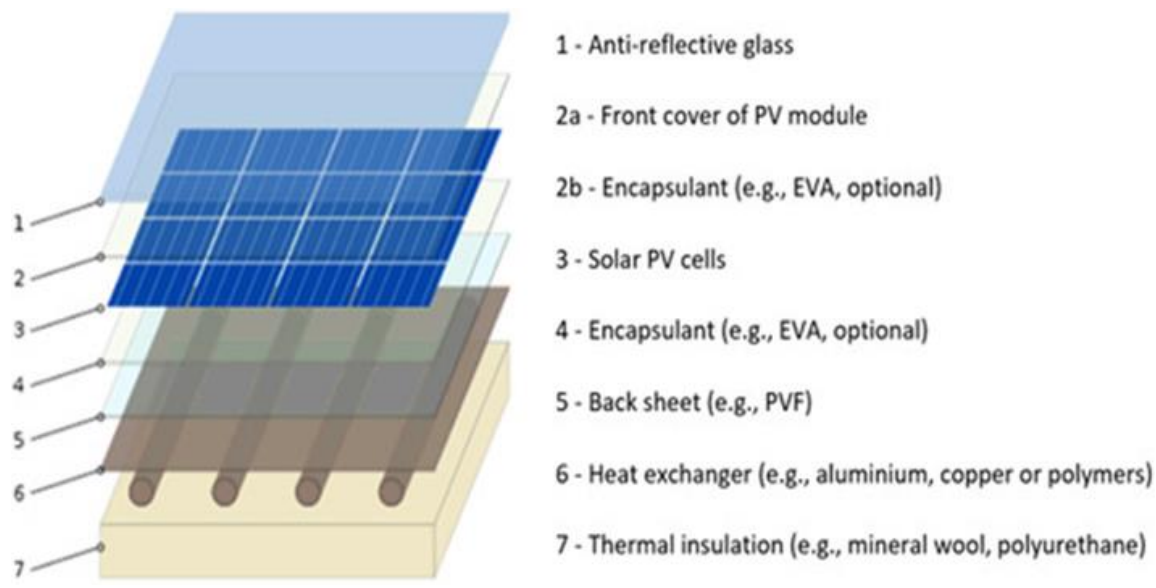

Fig. 3. A general PVT module diagram

Table 2

Material properties $[7,25,26]$

\begin{tabular}{|c|c|c|c|}
\hline Material & $\begin{array}{l}\text { Thermal Conductivity (k) } \\
\frac{W}{\boldsymbol{m}^{1} \boldsymbol{K}^{1}}\end{array}$ & $\begin{array}{l}\text { Specific Heat (Cp) } \\
\frac{\boldsymbol{J}}{\boldsymbol{K} \boldsymbol{g}^{\mathbf{1}} \boldsymbol{K}^{\mathbf{1}}}\end{array}$ & $\begin{array}{l}\text { Density } \\
\frac{\boldsymbol{K g}}{\boldsymbol{m}^{3}}\end{array}$ \\
\hline Glass & 1.3 & 749 & 2200 \\
\hline PV & 148 & 700 & 2330 \\
\hline Copper & 387.6 & 381 & 8978 \\
\hline Thermal Paste & 1 & 650 & 2400 \\
\hline Insulation & 0.173 & 700 & 2310 \\
\hline Water & 0.6 & 4182 & 998.2 \\
\hline
\end{tabular}

Table 3

PVT layer dimensions [7]

\begin{tabular}{ll}
\hline Layer & Dimensions $(\mathrm{L} \times \mathrm{W} \times \mathrm{H})$ \\
\hline Glass & $0.63 \mathrm{~m} \times 0.54 \mathrm{~m} \times 0.003 \mathrm{~m}$ \\
$\mathrm{PV}$ & $0.63 \mathrm{~m} \times 0.54 \mathrm{~m} \times 0.0003 \mathrm{~m}$ \\
Absorber Plate & $0.63 \mathrm{~m} \times 0.54 \mathrm{~m} \times 0.0004 \mathrm{~m}$ \\
Insulator & $0.63 \mathrm{~m} \times 0.54 \mathrm{~m} \times 0.013 \mathrm{~m}$ \\
\hline
\end{tabular}




\subsection{Model Discretization}

The study is conducted using the Computational fluid dynamics (CFD) method. By considering the PVT system as a control volume, the following governing equations for continuity, momentum, and energy are used $[7,27]$

Continuity equation

$$
\nabla \cdot\left(\rho_{f} V_{f}\right)=0
$$

Momentum equation

$$
\nabla \cdot\left(\rho_{f} V_{f} V_{f}\right)=-\nabla P+\nabla \cdot\left(\mu_{f} \nabla V_{f}\right)
$$

Flow Energy equation

$$
\nabla \cdot\left(V_{f} \rho_{f} C_{p, f} T_{f}\right)=\nabla \cdot\left(k_{f} \nabla T_{f}\right)
$$

Energy equation for solids

$k_{s} \nabla\left(T_{s}\right)=0$

where ' $V_{f}$ ' is the fluid velocity, and ' $P$ ' is pressure. Subscript ' $f$ ' indicates fluid, where ' $s$ ' indicates solid.

The equations are discretized and solved using the pressure-based finite volume method using ANSYS Fluent 19.2. For the mass flow rate of $40 \mathrm{~kg} / \mathrm{h}$, the Reynolds number is near but under the critical Reynolds number of 2300 . Therefore, the flow is considered laminar for a flow rate under 40 $\mathrm{Kg} / \mathrm{h}$ and turbulent over $40 \mathrm{Kg} / \mathrm{h}$. Furthermore, the flow is considered steady, fully developed, and incompressible. The pressure and velocity are coupled using the SIMPLE scheme. The second-order upwind interpolation scheme is used for convective terms. The top of the glass surface has the wall condition with the heat generation rate equal to the absorbed solar irradiation. About $10 \%$ of it is assumed to be absorbed by the glass, while the PV module absorbs the rest. In addition, convection occurs in the ambient air. The ambient wind speed is assumed to be less than $5 \mathrm{~m} / \mathrm{s}$. For which the convective heat transfer can be calculated using the following equation [28]

$h_{w}=5.7+3.8 V_{w}$ for $V_{w}<5 \mathrm{~m} / \mathrm{s}$

where ' $h{ }_{w}$ ' is the convective heat transfer co-efficient, and ' $V_{w}$ ' is the wind speed.

Taking the PVT system as a control volume and assuming steady-state conditions applied, the energy balance for the PVT system can be expressed as

$E_{\text {sun }}+E_{\text {mass,in }}=E_{\text {el }}+E_{\text {mass,out }}+E_{\text {loss }}$

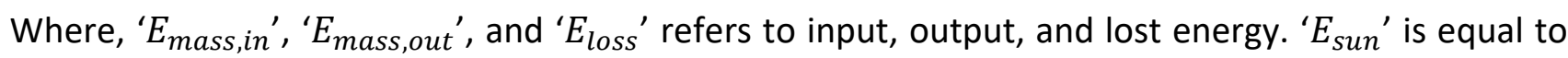
the absorbed solar irradiation, and it can be expressed as

$E_{\text {sun }}=G \cdot A c \cdot \tau_{g} \cdot \alpha_{\text {cell }}$ 
' $G$ ' is the rate of total solar irradiation, ' $A c$ ' is the surface area of the collector, ' $\tau_{g}$ ' is the transmissivity of the glass cover, while ' $\alpha_{\text {cell }}$ ' is the absorptivity of the PV cells. The energy relating to mass flow is calculated as

$E_{\text {mass }, \text { out }}-E_{\text {mass,in }}=E_{\text {th }}=m_{f} C_{p, f} \cdot\left(T_{f, \text { out }}-T_{f, \text { in }}\right)$

where ' $m_{f}$ ' is the mass flow rate and ' $T_{f, \text { in }}$ ' the fluid temperature. The thermal efficiency of the system is calculated by

$\eta_{t h}=\frac{E_{t h}}{E_{\text {sun }}}=m_{f} C_{p, f} \cdot \frac{T_{f, o u t}-T_{f, \text { in }}}{G \cdot A c \cdot \tau_{g} \cdot \alpha_{c e l l}}$

The electrical energy efficiency of the PVT system is calculated from the equation [29]

$\eta_{e l}=\frac{E_{e l}}{E_{\text {sun }}}=\eta_{r} \cdot\left[1-0.0045 \cdot\left(T_{\text {cell }}-298.15\right)\right]$

where ' $\eta_{r}$ ' is the PV module efficiency, and ' $T_{\text {cell }}$ ' is the temperature of the PV cell. This equation is used for numerical analysis. For experimental analysis, the electrical energy efficiency of PVT system is found by Yazdanifard et al., [30]

$\eta_{e l}=\frac{E_{e l}}{E_{\text {sun }}}=\frac{V_{o c} \cdot I_{s c} \cdot F F}{G \cdot A c \cdot \tau_{g} \cdot \alpha_{c e l l}}$

where ' $V_{O C}$ ' and ' $I_{S c}$ ' stand for open-circuit voltage and short circuit current of the PV module, respectively. ' $F F$ ' is the fill factor, which is calculated by Yazdanifard et al., [30]

$F F=\frac{V_{\max } \cdot I_{\max }}{V_{o c} \cdot I_{s c}}$

The overall efficiency is the sum of thermal efficiency and electrical efficiency. The heat transfer in the PVT system due to the incident solar irradiation is simulated by the heat flux method [26]. The temperature distribution uniformity is checked by plotting the temperature across a line in the middle of the PV module's top surface.

\subsection{Simulation Assumptions}

Following assumptions are made for the model.

- Steady-state conditions are assumed.

- Perfect contact between all components is assumed.

- EVA layer is assumed not to affect the model thermally $(100 \%$ transparency) $[31,41]$.

- The thermophysical properties of various materials in the model are assumed to be constant.

- Solar Irradiance is assumed to be incident on the PV panel normally for maximum performance.

- Some space on the PV panel will be left for the junction box. 
Table 4 shows the values of the input parameters to the equations.

Table 4

Input parameters for the equations

\begin{tabular}{ll}
\hline Parameter & Value \\
\hline Specific Heat $(\boldsymbol{C} \boldsymbol{p}) \frac{J}{\boldsymbol{K}^{1} \boldsymbol{K}^{\mathbf{1}}}$ & 4182 \\
Surface Area of The Collector $(\boldsymbol{A c}) \boldsymbol{m}^{\mathbf{2}}$ & $0.54 \times 0.63$ \\
Rate of Total solar Irradiation $(\boldsymbol{G}) \mathrm{W} / \mathrm{m}^{\wedge} 2$ & 1000 \\
Transmissivity of the glass cover $\left(\boldsymbol{\tau}_{\boldsymbol{g}}\right)$ & 0.9 \\
Absorptivity of the PV cells $\left(\boldsymbol{\alpha}_{\text {cell }}\right)$ & 0.9 \\
\hline
\end{tabular}

\subsection{Custom Absorber Design}

From the literature review, it is found that the spiral absorber is most efficient. However, a simple spiral absorber cannot be housed in the PVT system without making flow design changes to accommodate the junction box. Instead of fashioning a single spiral absorber to leave some space for the junction box, two spiral absorbers connected, as shown in Figure 4, are proposed. This way, ample space is left for the junction box, and the absorber itself provides a decent flow design without the use of complicated machining techniques. On top of that, the overall pipe length is increased which will lead to more heat transfer to the working fluid. The custom absorber has an approximate pipe length of $12.85 \mathrm{~m}$ where the serpentine design used by Hosseinzadeh et al., [7] has an approximate pipe length of $7.53 \mathrm{~m}$.

The collector pipe is made of copper which has an inner diameter of $0.01 \mathrm{~m}$ and an outer diameter of $0.012 \mathrm{~m}$. The custom absorber design is shown in Figure 4 . The pipe spacing is kept at $0.002 \mathrm{~m}$ to ensure more contact area between the pipe and the plate. The pipe spacing is a bit extended in areas like the centre of each spiral loop and the middle region where the loops are connected, where the pipe spacing is $0.032 \mathrm{~m}$ and $0.04 \mathrm{~m}$, respectively. This is done for model design simplification and to allow simulation with a relatively small mesh count. If the pipe spacing is to be kept consistent throughout, there will be more tight spaces in geometry which will require a much finer mesh to avoid invalid dihedral angles.

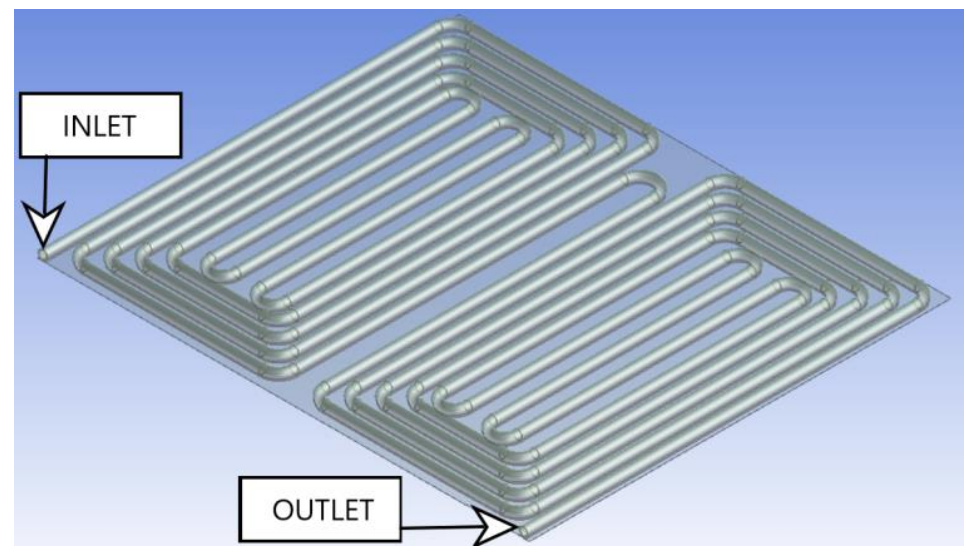

Fig. 4. The Custom Absorber Design

Many custom designs have been proposed in the literature, the novelty of this design is its simplistic geometry. In most cases, to accommodate for the junction box usually, major changes in the flow design are made which brings up complications especially if the pipe spacing is to be kept small for temperature uniformity. This design is two standard sets of spiral absorbers connected. This 
design is relatively less complicated for this reason and it allows room for adjusting the pipe spacing without much complication.

\section{Results}

\subsection{Model Validation}

The simulation model is verified with the experimental data taken from a study by Hosseinzadeh et al., [7]. The experiment takes place in Mashhad, Iran. The specifications under standard testing conditions of the monocrystalline PV module used in the experiment are detailed in Table 5.

\begin{tabular}{ll}
$\begin{array}{l}\text { Table } \mathbf{5} \\
\text { Parameter specification }\end{array}$ & \\
\hline Parameter & Specification \\
\hline Maximum power (W) & 40 \\
Number of cells & 36 \\
Fill factor & 0.726 \\
Open-circuit voltage (V) & 21.6 \\
Short-circuit current (A) & 2.57 \\
Optimum operating voltage (V) & 17.6 \\
Optimum operating current (A) & 2.29 \\
Cell efficiency (\%) & 16 \\
Module efficiency (\%) & 15 \\
\hline
\end{tabular}

In the experiment, the PV module is attached to a copper plate, which is soldered to a serpentine copper absorber and an insulating body around it. The working fluid is circulated at a flow rate of 30 $\mathrm{kg} / \mathrm{h}$. The experiment takes place in Mashhad, Iran. The readings are taken on selected days in August and September [7]. The experiment results are compared to the results of a simulation model. For validation, the same model was recreated with the same boundary conditions. The ambient temperature, incident solar irradiance, and the water inlet temperature are shown in Figure 5.

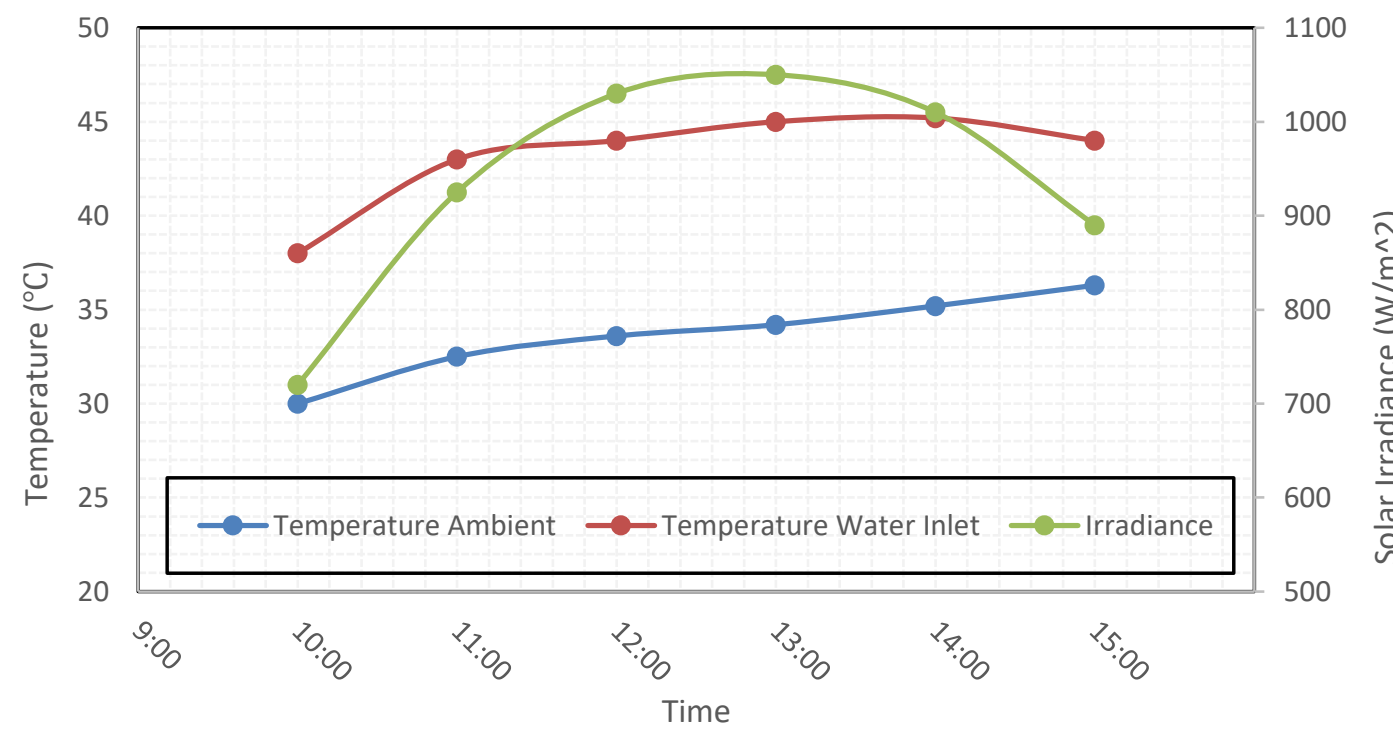

Fig. 5. Initial ambient, coolant inlet temperatures and incident solar irradiance with respect to time [7] 
Using the data from the experiment, the simulation model is verified by recreating the absorber design shown in Figure 6. Under the same conditions as the experiment, the simulation is carried out. The results of the simulation and the experiment are compared and validated. The comparison is shown in Figure 7 and Figure 8.

The percentage error between the experimental data and simulation result is found to be $7.8 \%$ and $7 \%$ for PV temperature and outlet temperature, respectively. The highest percentage error is $9.44 \%$, where the lowest is $3.17 \%$. The mean squared deviation is 18.2 and 11.4 for PV and water outlets, respectively. This higher percentage of error is present due to model simplification undertaken due to hardware limitations. It should be noted that this high percentage of error will lead to errors in the efficiency calculation of the PVT system as well. The variation of thermal and electrical efficiency between simulated and experimental data is shown in Figure 9 and Figure 10.

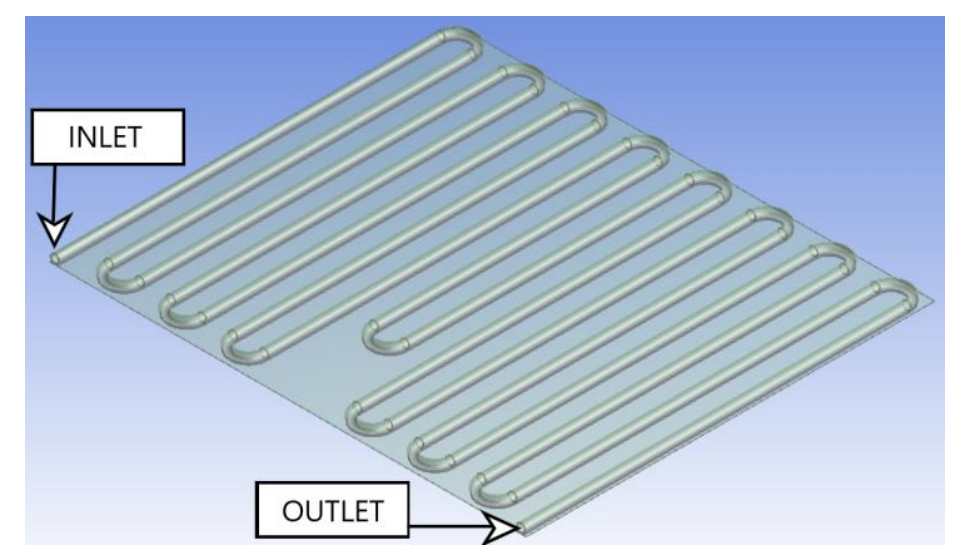

Fig. 6. Serpentine absorber design [7]

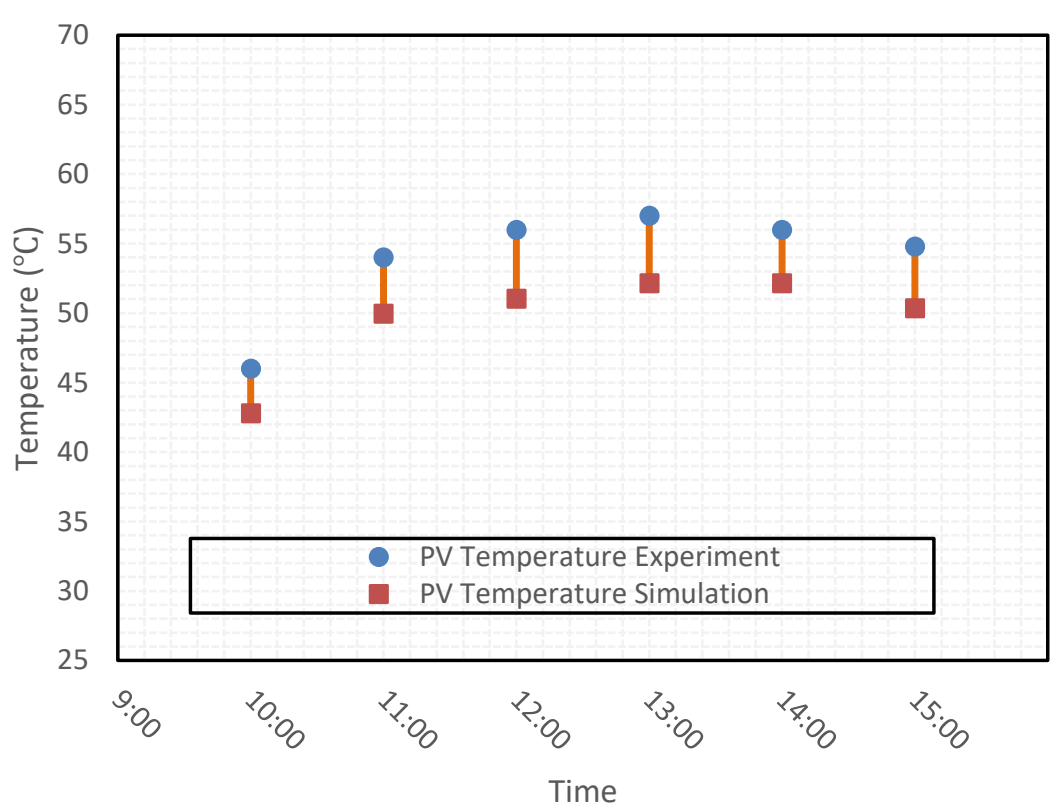

Fig. 7. PV temperature experimental and simulated with respect to time 


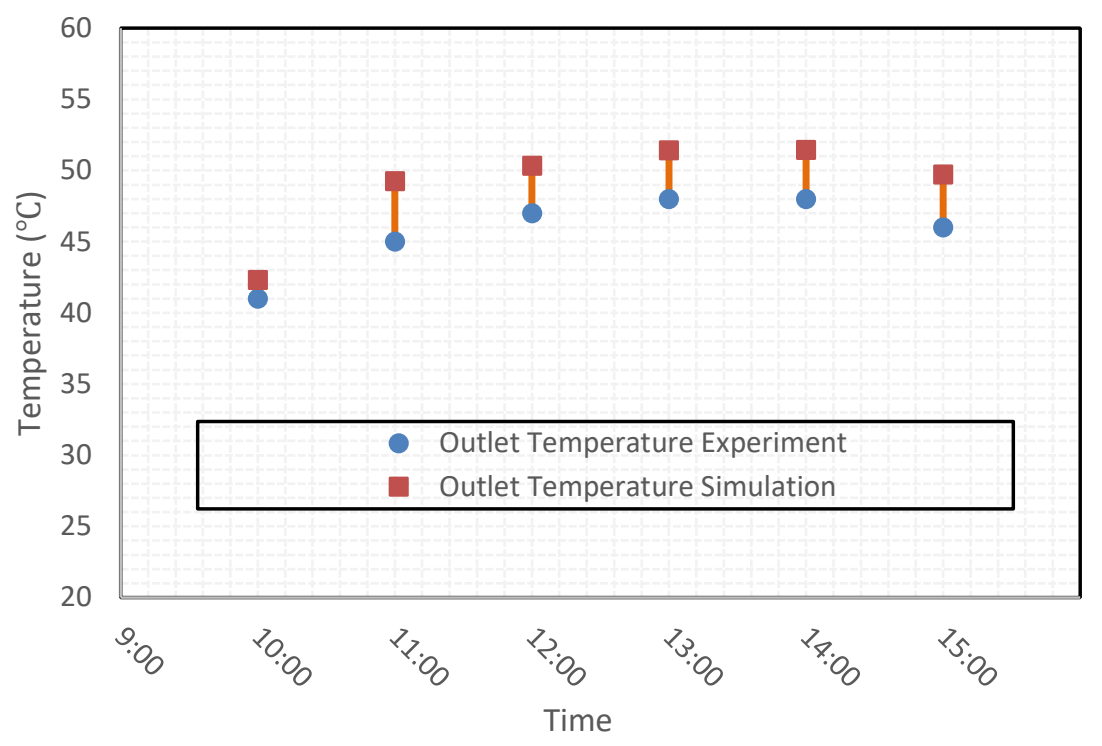

Fig. 8. Coolant outlet temperature experimental and simulated with respect to time

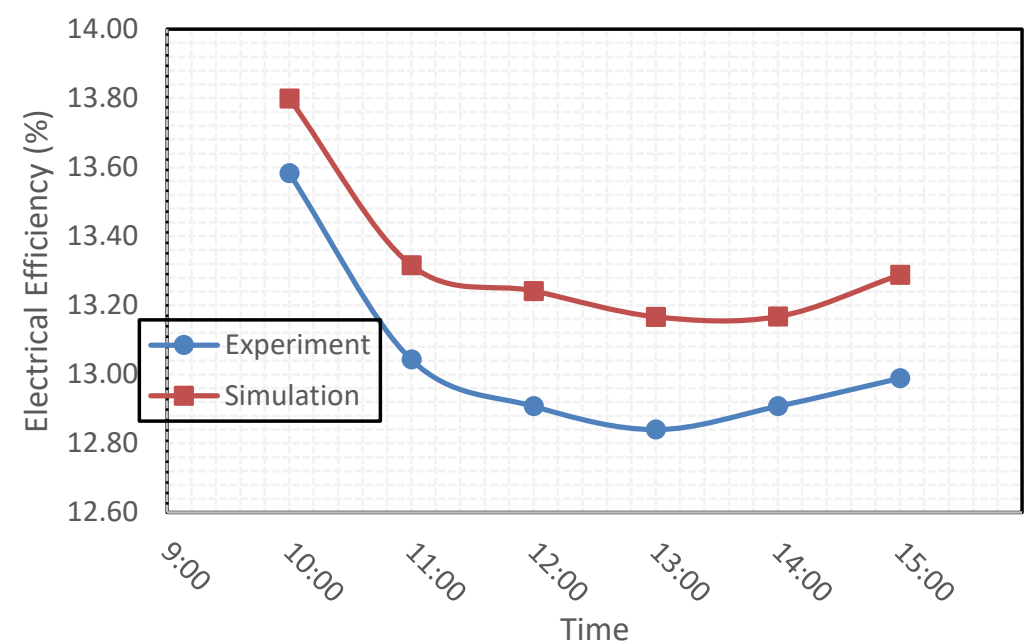

Fig. 9. Electrical efficiency comparison

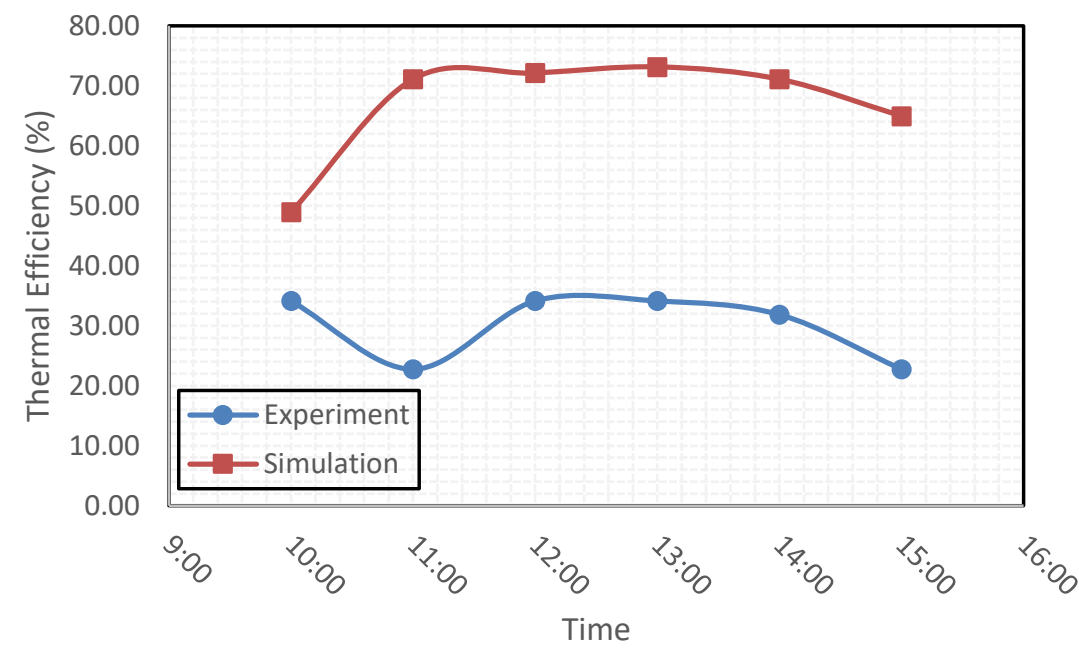

Fig. 10. Thermal efficiency comparison 
As can be seen from Figure 9 and Figure 10 above, due to a relatively high percentage error, the electrical and thermal efficiencies have high margins of error, especially for thermal efficiency. On average, the electrical efficiency of the simulation is higher than the experiment data by a difference of $0.28 \%$. With the maximum and minimum differences being $0.33 \%$ and $0.22 \%$, respectively. Whereas the thermal efficiency on average for the simulation is higher than the experiment data by a difference of $36.94 \%$ with the maximum and minimum differences coming in at $48.92 \%$ and 73.16 $\%$, respectively. As the simulation setup is limited by computational power, this error cannot be reduced, but it can be accounted for in the comparison study. The unusually high margin of error can be attributed to differences in the simulation model undertaken for the sake of simplicity. These differences are as follows

- The simulation model does not utilize any radiation modelling whereas the model used by Hosseinzadeh et al., [7] does utilize radiation modelling.

- The insulation material is also not simulated directly by Hosseinzadeh et al., [7].

- No thermal paste is used by Hosseinzadeh et al., [7].

- Mesh type and the software used for meshing are different.

\subsection{Grid Independence Test}

Meshing is done in ANSYS Fluent Meshing 19.2 using the polyhedral volume meshing as shown in Figure 11. Multiple mesh element sizes were tested. The mesh settings that were tested had a mesh count of $2.9 \mathrm{M}, 3.4 \mathrm{M}, 3.98 \mathrm{M}$, and $4.78 \mathrm{M}$. The results of the simulations using these different mesh counts are shown in Table 6.

\section{Table 6}

Coolant outlet and PV temperature with respect to mesh size

\begin{tabular}{lll}
\hline Mesh Size in Million (M) & PV Temperature $\left({ }^{\circ} \mathrm{C}\right)$ & Outlet Temperature $\left({ }^{\circ} \mathrm{C}\right)$ \\
\hline 2.9 & 51.05 & 50.34 \\
3.4 & 51.07 & 50.35 \\
3.98 & 51.05 & 50.35 \\
4.78 & 51.03 & 50.35 \\
\hline
\end{tabular}

Although the results vary with change in mesh size, due to hardware limitations and the fact that the degree of change is insignificant, the mesh size is not further refined to increase the mesh count. The mesh has a minimum orthogonal quality of 0.2 , a maximum aspect ratio of 27 , and a maximum skewness of 0.78 .

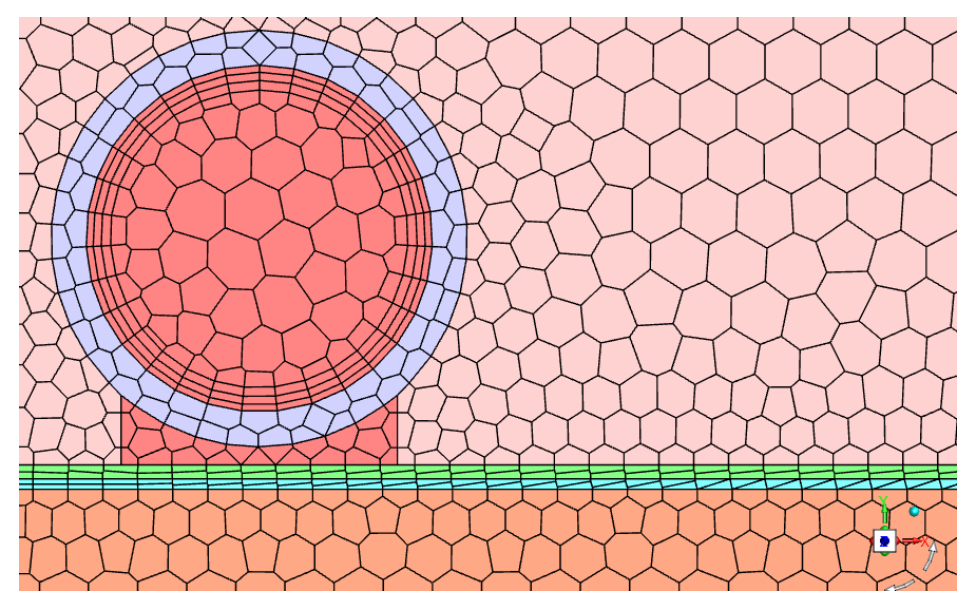

Fig. 11. A view of the mesh of the PVT system 


\subsection{Absorber Performance Comparison}

After the model verification is done, the PVT system is simulated using both absorber designs under the same conditions as shown in Table 7. The uniformity of the PVT system using the custom absorber design and the serpentine design by Hosseinzadeh et al., [7] is tested. After taking the study of Hosseinzadeh et al., [7] into consideration, where he found the ideal conditions for maximum efficiency, the following operating conditions are chosen as base conditions for comparison:

Table 7

Operating parameters

\begin{tabular}{ll}
\hline Parameter & Value \\
\hline Wind Speed $(\mathrm{m} / \mathrm{s})$ & 5 \\
Inlet Temperature $\left({ }^{\circ} \mathrm{C}\right)$ & 30 \\
Ambient Temperature $\left({ }^{\circ} \mathrm{C}\right)$ & 30 \\
Coolant Mass Flow Rate $(\mathrm{Kg} / \mathrm{h})$ & 30 \\
Incident Solar Irradiance $\left(\mathrm{w} / \mathrm{m}^{\wedge} 2\right)$ & 1000 \\
\hline
\end{tabular}

\subsubsection{Serpentine absorber}

In the serpentine absorber configuration used by Hosseinzadeh et al., [7], the average surface PV temperature and the coolant outlet temperature are found to be $38.88^{\circ} \mathrm{C}$ and $37.96^{\circ} \mathrm{C}$, respectively. The temperature distribution across the PV module surface and the temperature contour of water are shown in Figure 12.

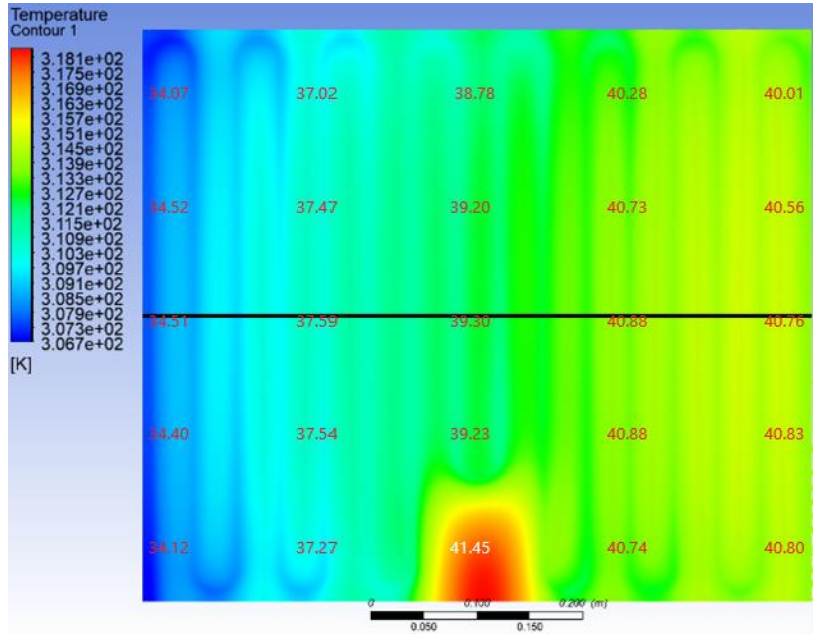

(a)

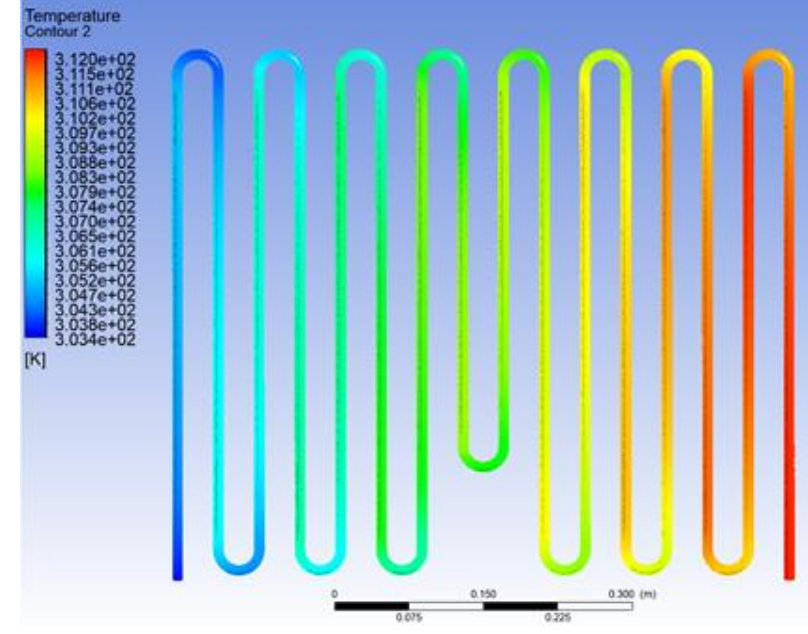

(b)

Fig. 12. Serpentine absorber contour (a) Top PV surface (b) Absorber

\subsubsection{Custom absorber}

For the custom absorber design, the average PV surface temperature and the coolant outlet temperature are found to be $37.63^{\circ} \mathrm{C}$ and $38.11^{\circ} \mathrm{C}$. The temperature contours of the PV surface and water are shown in Figure 13. 


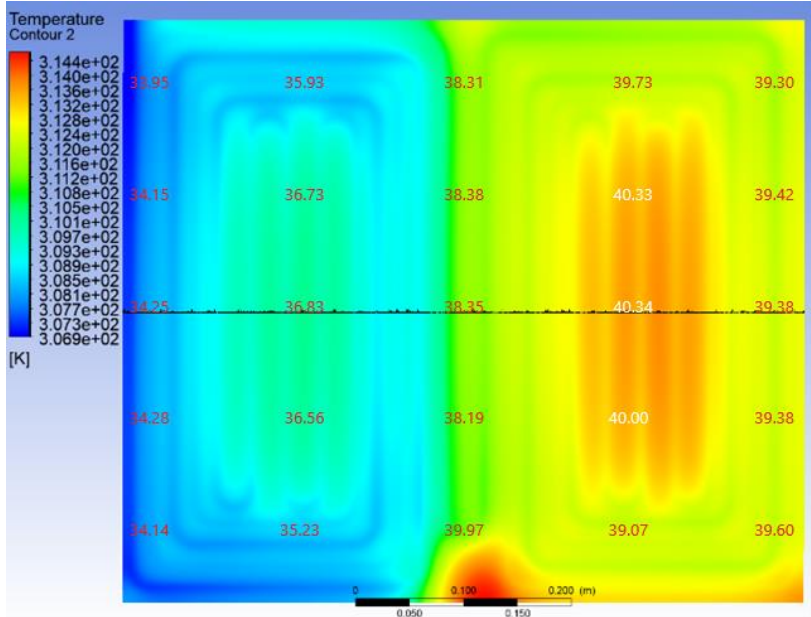

(a)

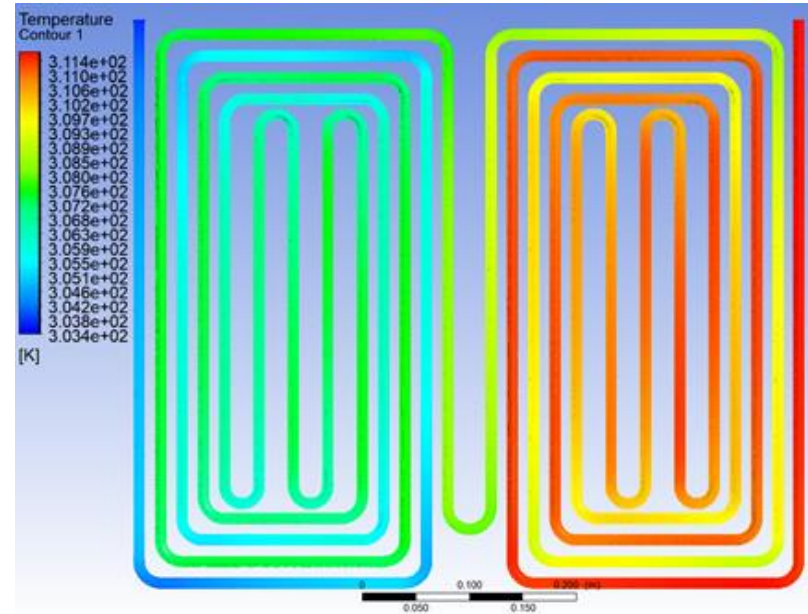

(b)

Fig. 13. Custom Proposed Design (a) Top PV surface (b) absorber

\subsubsection{Discussion}

To compare the temperature uniformity, the temperature distribution across a line located at the centre of the PV surface is shown in Figure 14. The black line shows the location of the line in Figure 12 and Figure 13.

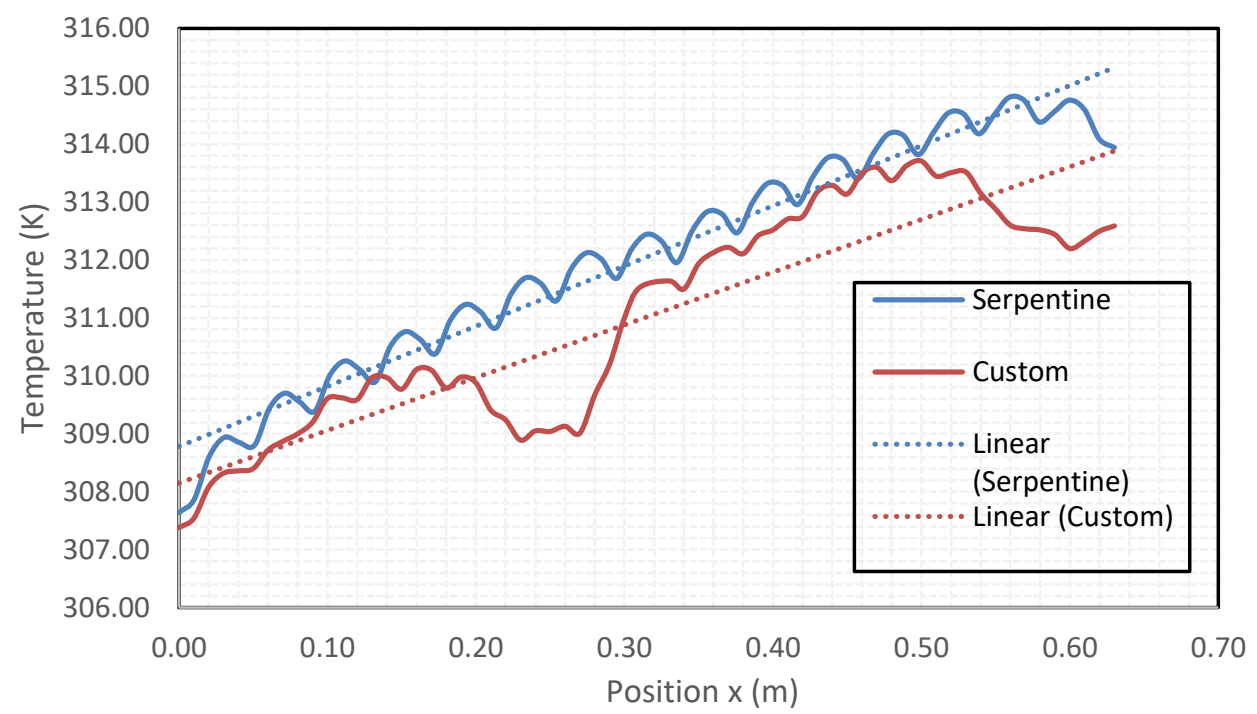

Fig. 14. Temperature distribution on a line at the centre of the PV top surface for both absorbers

When comparing the temperature on a line in the middle of the PV surface, it can be seen that the temperature of the PV when using a custom absorber varies from $34.23^{\circ} \mathrm{C}$ to $39.44^{\circ} \mathrm{C}$, whereas for design of Hosseinzadeh et al., [7], it varies from $34.49^{\circ} \mathrm{C}$ to $40.79^{\circ} \mathrm{C}$. Across the PV, the highest temperature observed when using the custom absorber is $41.25^{\circ} \mathrm{C}$, and for Hosseinzadeh et al., [7] is $44.95^{\circ} \mathrm{C}$. The difference in temperatures is due to the pipe spacing, pipe length, and absorber configuration, as evident from the literature. From Figure 14, the temperature uniformity across the PV surface when using the custom absorber can be seen as better than that of the serpentine absorber as more cells are operating at near-identical temperatures. However, the uniformity is 
observed to deteriorate at locations where the pipe spacing is increased due to design simplicity. The sharp decline and rise between $0.2 \mathrm{~m}$ and $0.3 \mathrm{~m}$ can be explained by looking at the flow design.

In the sector between $0.2 \mathrm{~m}$ and $0.3 \mathrm{~m}$, the tube section is close to inlet. The water in that section is closer to the water entry point. Therefore, the water in this sector has a more prominent cooling effect because of its lower temperature. The next pipe section is further away from the water entry point. Still, when compared to the serpentine design, the temperature variation is not as fluctuant. For the custom absorber, most cells are at near-identical temperatures except for the region where pipe spacing is higher than $0.002 \mathrm{~m}$. For the serpentine absorber, the temperature is observed to be fluctuating periodically for almost all of the cells. The thermal efficiency obtained for the custom and the serpentine absorber is $92.31 \%$ and $90.59 \%$, respectively.

Because of this better uniformity of temperature across the module, the custom absorber is found to be more efficient compared to the serpentine design as it results in average electrical efficiency of $14.15 \%$ as compared to $14.06 \%$ of the serpentine absorber.

\subsection{Error Compensation}

From the model validation, we found that the error in calculated thermal and electrical efficiency is relatively high. Using that data, the actually calculated efficiencies can be estimated. The actual calculated thermal and electrical efficiency range is shown in Table 8.

Judging by the average error, the thermal and electrical efficiency for the custom absorber is $55.37 \%$ and $13.87 \%$, respectively. Whereas for the serpentine absorber, the thermal and electrical efficiencies are $53.65 \%$ and $13.78 \%$.

Table 8

Actual calculated thermal and electrical efficiency ranges after accommodating for error margins

\begin{tabular}{lll}
\hline Absorber Type & Electrical efficiency range (\%) & Thermal efficiency range (\%) \\
\hline Custom & $13.82-13.93$ & $19.15-43.39$ \\
Serpentine [7] & $13.73-13.84$ & $17.43-41.67$ \\
\hline
\end{tabular}

\section{Conclusions}

The change in range for the custom absorber and the serpentine absorber and the average efficiency estimation would suggest the custom absorber will have better efficiency. The custom absorber design provides an estimated percentage improvement of $3.21 \%$ and $0.65 \%$ over the serpentine absorber to the thermal and electrical efficiency of the PV, respectively. In terms of temperature, the new absorber design helped achieve a $37.63^{\circ} \mathrm{C}$ average PV temperature and $38.11^{\circ} \mathrm{C}$ coolant outlet temperature. Where the serpentine absorber had an average PV temperature of $38.88^{\circ} \mathrm{C}$ and $37.96^{\circ} \mathrm{C}$ coolant outlet temperature. This gain in performance is attributed to lower and more uniformly distributed temperature across the PV. Many custom designs have been proposed in the literature, the novelty of this design is its simplistic geometry. In most cases, to accommodate for the junction box usually, major changes in the flow design are made which brings up complications especially if the pipe spacing is to be kept small for temperature uniformity. This design is two standard sets of spiral absorbers connected. This design is relatively less complicated for this reason and it allows room for adjusting the pipe spacing without much complication. The simulation study reaffirms the fact that better temperature uniformity on the PV module results in better performance. In the future, the absorber can be tested experimentally to verify the performance improvements. The absorber design can also be further refined to keep the pipe spacing 
consisting throughout the PV panel (This will require a more refined mesh to avoid invalid dihedral angles).

\section{Acknowledgement}

The author would like to thank the Faculty of Mechanical Engineering and Centre of Advanced Research on Energy (CARe), Applied Solar Energy Laboratory (ASEL), and Universiti Teknikal Malaysia Melaka (UTeM) for providing the facilities and equipment to support this research. The Malaysian Ministry of Higher Education funded this work under the grant FRGS/2018/FKM-CARe/F00368.

\section{References}

[1] Ahmad, Tanveer, and Dongdong Zhang. "A critical review of comparative global historical energy consumption and future demand: The story told so far." Energy Reports 6 (2020): 1973-1991. https://doi.org/10.1016/i.egyr.2020.07.020

[2] Sardouei, Masoud Mohammadi, Hamid Mortezapour, and Kazem Jafari Naeimi. "Temperature distribution and efficiency assessment of different PVT water collector designs." Sādhanā 43, no. 6 (2018): 1-13. https://doi.org/10.1007/s12046-018-0826-x

[3] Mbungu, Nsilulu T., Raj M. Naidoo, Ramesh C. Bansal, Mukwanga W. Siti, and Diambomba H. Tungadio. "An overview of renewable energy resources and grid integration for commercial building applications." Journal of Energy Storage 29 (2020): 101385. https://doi.org/10.1016/i.est.2020.101385

[4] Walmsley, Timothy G., Michael RW Walmsley, Petar S. Varbanov, and Jiří J. Klemeš. "Energy Ratio analysis and accounting for renewable and non-renewable electricity generation: A review." Renewable and Sustainable Energy Reviews 98 (2018): 328-345. https://doi.org/10.1016/i.rser.2018.09.034

[5] Abdullah, Ahmed L., S. Misha, N. Tamaldin, M. A. M. Rosli, and F. A. Sachit. "Photovoltaic thermal/solar (PVT) collector (PVT) system based on fluid absorber design: A review." Journal of Advanced Research in Fluid Mechanics and Thermal Sciences 48, no. 2 (2018): 196-208.

[6] Sachit, F. A., Noreffendy Tamaldin, M. A. M. Rosli, S. Misha, and A. L. Abdullah. "Current progress on flat-plate water collector design in photovoltaic thermal (PV/T) systems: A Review." Journal of Advanced Research in Dynamical and Control Systems 10 (2018): 680-694.

[7] Hosseinzadeh, Mohammad, Ali Salari, Mohammad Sardarabadi, and Mohammad Passandideh-Fard. "Optimization and parametric analysis of a nanofluid based photovoltaic thermal system: 3D numerical model with experimental validation." Energy Conversion and Management $160 \quad$ (2018): 93-108. https://doi.org/10.1016/i.enconman.2018.01.006

[8] Tuncel, B., T. Ozden, R. S. Balog, and B. G. Akinoglu. "Dynamic thermal modelling of PV performance and effect of heat capacity on the module temperature." Case Studies in Thermal Engineering 22 (2020): 100754. https://doi.org/10.1016/i.csite.2020.100754

[9] Bahaidarah, Haitham MS, Ahmer AB Baloch, and Palanichamy Gandhidasan. "Uniform cooling of photovoltaic panels: A review." Renewable and Sustainable Energy Reviews 57 (2016): 1520-1544. https://doi.org/10.1016/i.rser.2015.12.064

[10] Al-Waeli, Ali H., K. Sopian, Hussein A. Kazem, and Miqdam T. Chaichan. "Photovoltaic solar thermal (PV/T) collectors past, present and future: A review." International Journal of Applied Engineering Research 11, no. 22 (2016): 1075710765.

[11] Syafiqah, Z., N. A. M. Amin, Y. M. Irwan, M. S. A. Majid, and N. A. Aziz. "Simulation study of air and water cooled photovoltaic panel using ANSYS." In Journal of Physics: Conference Series, vol. 908, no. 1, p. 012074. IOP Publishing, 2017. https://doi.org/10.1088/1742-6596/908/1/012074

[12] Ahmed, Asmaa, Hasan Baig, Senthilarasu Sundaram, and Tapas K. Mallick. "Use of nanofluids in solar PV/thermal systems." International Journal of Photoenergy 2019 (2019): 1-18. https://doi.org/10.1155/2019/8039129

[13] Hissouf, Mohamed, Monssif Najim, and Adil Charef. "Numerical study of a covered Photovoltaic-Thermal Collector (PVT) enhancement using nanofluids." Solar Energy $199 \quad$ (2020): 115-127. https://doi.org/10.1016/j.solener.2020.01.083

[14] Fudholi, Ahmad, Nur Farhana Mohd Razali, Mohammad H. Yazdi, Adnan Ibrahim, Mohd Hafidz Ruslan, Mohd Yusof Othman, and Kamaruzzaman Sopian. "TiO2/water-based photovoltaic thermal (PVT) collector: Novel theoretical approach." Energy 183 (2019): 305-314. https://doi.org/10.1016/j.energy.2019.06.143

[15] Abdullah, Amira Lateef, S. Misha, N. Tamaldin, M. A. M. Rosli, and F. A. Sachit. "Theoretical study and indoor experimental validation of performance of the new photovoltaic thermal solar collector (PVT) based water system." Case Studies in Thermal Engineering 18 (2020): 100595. https://doi.org/10.1016/i.csite.2020.100595 
[16] Misha, S., Amira Lateef Abdullah, N. Tamaldin, M. A. M. Rosli, and F. A. Sachit. "Simulation CFD and experimental investigation of PVT water system under natural Malaysian weather conditions." Energy Reports 6 (2020): 28-44. https://doi.org/10.1016/j.egyr.2019.11.162

[17] Rosli, Mohd Afzanizam Mohd, Yap Joon Ping, Suhaimi Misha, Mohd Zaid Akop, Kamaruzzaman Sopian, Sohif Mat, Ali Najah Al-Shamani, and Muhammad Asraf Saruni. "Simulation Study of Computational Fluid Dynamics on Photovoltaic Thermal Water Collector with Different Designs of Absorber Tube." Journal of Advanced Research in Fluid Mechanics and Thermal Sciences 52, no. 1 (2018): 12-22.

[18] Poredoš, Primož, Urban Tomc, Nada Petelin, Boris Vidrih, Uroš Flisar, and Andrej Kitanovski. "Numerical and experimental investigation of the energy and exergy performance of solar thermal, photovoltaic and photovoltaicthermal modules based on roll-bond heat exchangers." Energy Conversion and Management 210 (2020): 112674. https://doi.org/10.1016/j.enconman.2020.112674

[19] Shukla, A., Karunesh Kant, Atul Sharma, and Pascal Henry Biwole. "Cooling methodologies of photovoltaic module for enhancing electrical efficiency: A review." Solar Energy Materials and Solar Cells 160 (2017): 275-286. https://doi.org/10.1016/i.solmat.2016.10.047

[20] Zhu, Li, Robert F. Boehm, Yiping Wang, Christopher Halford, and Yong Sun. "Water immersion cooling of PV cells in a high concentration system." Solar Energy Materials and Solar Cells 95, no. 2 (2011): 538-545. https://doi.org/10.1016/i.solmat.2010.08.037

[21] Wang, Gang, Fasi Wang, Fan Shen, Zeshao Chen, and Peng Hu. "Novel design and thermodynamic analysis of a solar concentration PV and thermal combined system based on compact linear Fresnel reflector." Energy 180 (2019): 133-148. https://doi.org/10.1016/j.energy.2019.05.082

[22] Valizadeh, Mohammad, Faramarz Sarhaddi, and Mohsen Mahdavi Adeli. "Exergy performance assessment of a linear parabolic trough photovoltaic thermal collector." Renewable Energy 138 (2019): 1028-1041. https://doi.org/10.1016/i.renene.2019.02.039

[23] Yu, Y., H. Yang, J. Peng, and E. Long. "Performance comparisons of two flat-plate photovoltaic thermal collectors with different channel configurations." Energy 175 (2019): 300-308. https://doi.org/10.1016/i.energy.2019.03.054

[24] Abd El-Samie, Mostafa M., Xing Ju, Zheyang Zhang, Saadelnour Abdueljabbar Adam, Xinyu Pan, and Chao Xu. "Three-dimensional numerical investigation of a hybrid low concentrated photovoltaic/thermal system." Energy 190 (2020): 116436. https://doi.org/10.1016/j.energy.2019.116436

[25] Bellos, Evangelos, and Christos Tzivanidis. "Alternative designs of parabolic trough solar collectors." Progress in Energy and Combustion Science 71 (2019): 81-117. https://doi.org/10.1016/i.pecs.2018.11.001

[26] Adam, Saadelnour Abdueljabbar, Xing Ju, Zheyang Zhang, Mostafa M. Abd El-Samie, and Chao Xu. "Theoretical investigation of different CPVT configurations based on liquid absorption spectral beam filter." Energy 189 (2019): 116259. https://doi.org/10.1016/j.energy.2019.116259

[27] Jaaz, Ahed Hameed, Husam Abdulrasool Hasan, Kamaruzzaman Sopian, Mohd Hafidz Bin Haji Ruslan, and Saleem Hussain Zaidi. "Design and development of compound parabolic concentrating for photovoltaic solar collector." Renewable and Sustainable Energy Reviews 76 (2017): 1108-1121. https://doi.org/10.1016/j.rser.2017.03.127

[28] Jaaz, Ahed Hameed, Kamaruzzaman Sopian, and Tayser Sumer Gaaz. "Study of the electrical and thermal performances of photovoltaic thermal collector-compound parabolic concentrated." Results in Physics 9 (2018): 500-510. https://doi.org/10.1016/j.rinp.2018.03.004

[29] Proell, M., P. Osgyan, H. Karrer, and C. J. Brabec. "Experimental efficiency of a low concentrating CPC PVT flat plate collector." Solar Energy 147 (2017): 463-469. https://doi.org/10.1016/j.solener.2017.03.055

[30] Yazdanifard, Farideh, Ehsan Ebrahimnia-Bajestan, and Mehran Ameri. "Performance of a parabolic trough concentrating photovoltaic/thermal system: effects of flow regime, design parameters, and using nanofluids." Energy Conversion and Management 148 (2017): 1265-1277. https://doi.org/10.1016/i.enconman.2017.06.075

[31] Zhou, Jicheng, Haoyun Ke, and Xiaoqing Deng. "Experimental and CFD investigation on temperature distribution of a serpentine tube type photovoltaic/thermal collector." Solar Energy 174 (2018): 735-742. https://doi.org/10.1016/i.solener.2018.09.063

[32] Mohammed, Humaid, Manish Kumar, and Rajesh Gupta. "Bypass diode effect on temperature distribution in crystalline silicon photovoltaic module under partial shading." Solar Energy 208 (2020): 182-194. https://doi.org/10.1016/i.solener.2020.07.087

[33] Zhou, Jicheng, Qiang Yi, Yunyun Wang, and Zhibin Ye. "Temperature distribution of photovoltaic module based on finite element simulation." Solar Energy 111 (2015): 97-103. https://doi.org/10.1016/i.solener.2014.10.040

[34] Amanlou, Yasaman, Teymour Tavakoli Hashjin, Barat Ghobadian, and G. Najafi. "Air cooling low concentrated photovoltaic/thermal (LCPV/T) solar collector to approach uniform temperature distribution on the PV plate." Applied Thermal Engineering 141 (2018): 413-421. https://doi.org/10.1016/i.applthermaleng.2018.05.070

[35] Fayaz, Hussain, Rehena Nasrin, Nasrudin Abd Rahim, and Md Hasanuzzaman. "Energy and exergy analysis of the PVT system: Effect of nanofluid flow rate." Solar Energy 169 (2018): $217-230$. 
https://doi.org/10.1016/i.solener.2018.05.004

[36] Filipović, Petar, Damir Dović, Borjan Ranilović, and Ivan Horvat. "Numerical and experimental approach for evaluation of thermal performances of a polymer solar collector." Renewable and Sustainable Energy Reviews 112 (2019): 127-139. https://doi.org/10.1016/i.rser.2019.05.023

[37] Khanjari, Y., F. Pourfayaz, and A. B. Kasaeian. "Numerical investigation on using of nanofluid in a water-cooled photovoltaic thermal system." Energy Conversion and Management 122 (2016): 263-278. https://doi.org/10.1016/i.enconman.2016.05.083

[38] Sardarabadi, Mohammad, and Mohammad Passandideh-Fard. "Experimental and numerical study of metaloxides/water nanofluids as coolant in photovoltaic thermal systems (PVT)." Solar Energy Materials and Solar Cells 157 (2016): 533-542. https://doi.org/10.1016/i.solmat.2016.07.008

[39] Evans, D. L. "Simplified method for predicting photovoltaic array output." Solar Energy 27, no. 6 (1981): 555-560. https://doi.org/10.1016/0038-092X(81)90051-7

[40] Bayrak, Fatih, Nidal Abu-Hamdeh, Khaled A. Alnefaie, and Hakan F. Öztop. "A review on exergy analysis of solar electricity production." Renewable and Sustainable Energy Reviews 74 (2017): 755-770. https://doi.org/10.1016/i.rser.2017.03.012

[41] Bahaidarah, H., Abdul Subhan, P. Gandhidasan, and S. Rehman. "Performance evaluation of a PV (photovoltaic) module by back surface water cooling for hot climatic conditions." Energy 59 (2013): 445-453. https://doi.org/10.1016/j.energy.2013.07.050 